\title{
PARAMETERS OF LANGUAGE MODELING OF EMOTIONAL SITUATIONS IN THE LITERARY TEXT
}

\author{
Larisa A. Kiseleva \\ Bashkir State University, Ufa, Russia
}

\begin{abstract}
The paper reveals the main parameters of language modeling of emotions in the literary text, such as causation, temporal localization, intensity, external manifestation. Using the material of stories of the collection Dark alleys by I.A. Bunin, we analyze lexical and phraseological designates of emotion of fear which specify these parameters. Thus, the parameter of the causality of fear combines such particular characteristics as the 'objectivity of emotion', 'internal / external causation of emotion', 'connection with the intellectual and volitional spheres', etc.; time parameter - 'temporal actuality (episodicity) / timelessness (stability) of emotion', 'static / dynamic emotion', 'phasic flow of emotion', etc. It is revealed that I.A. Bunin's prose emphasizes not only individual aspects of emotions but also specific signs within these aspects. Thus, when portraying fear, the parameter of the external expression of emotion takes the leading place, and inside it - the sign 'physiological symptomatology'. The peculiarity of the linguistic expression of these parameters is determined, on the one hand, by the systemic relations of the emotions, which are projected onto the semantic space of the text, and, on the other hand, by the associative links of these units within the specific works. In the prose of I.A. Bunin fear is described not only as a simple emotional situation, but also as a component of complex emotions, denoted by oxymorons such as the rapture of horror, fear of happiness, etc. Due to the use of such multicomponent names, the boundaries of the emotional world of heroes are widened, and the possibility of "combining" different experiences is emphasized.

Key words: emotions, emotion of fear, literary text, Ivan Bunin, semantics, language modeling, emotive.

Citation. Kiseleva L.A. Parameters of Language Modeling of Emotional Situations in the Literary Text. Vestnik Volgogradskogo gosudarstvennogo universiteta. Seriya 2, Yazykoznanie [Science Journal of Volgograd State University. Linguistics], 2018, vol. 17, no. 3, pp. 108-118. (in Russian). DOI: https://doi.org/10.15688/ jvolsu2.2018.3.11
\end{abstract}

\section{ПАРАМЕТРЫ ЯЗЫКОВОГО МОДЕЛИРОВАНИЯ ЭМОЦИОНАЛЬНЫХ СИТУАЦИЙ В ХУДОЖЕСТВЕННОМ ТЕКСТЕ}

\author{
Лариса Айратовна Киселева \\ Башкирский государственный университет, г. Уфа, Россия
}

\begin{abstract}
Аннотация. В статье охарактеризованы основные параметры языкового моделирования эмоций в художественном тексте: причинная обусловленность, временная локализованность, интенсивность, внешнее проявление. На материале рассказов цикла «Темные аллеи» И.А. Бунина комплексно рассмотрены лексикофразеологические обозначения эмоции страха, которые конкретизируют данные параметры. Показано, что параметр причинной обусловленности страха объединяет такие частные признаки, как 'предметность эмоции', 'внутренняя / внешняя причинная обусловленность', 'связь с интеллектуальной и волевой сферами'; временно́й параметр - 'временная актуализованность (эпизодичность) / вневременность (стабильность)', ‘статичность / динамичность', ‘фазисность протекания'. Установлено, что в прозе И.А. Бунина при описании разных видов эмоций акцентируются не только их отдельные аспекты, но и признаки внутри них: при изображении страха ведущее место занимает параметр внешнего выражения эмоции, а внутри него - признак 'физиологическая симптоматика'. В рассказах страх предстает не только как простая эмоциональная
\end{abstract}


ситуация, но и как компонент сложных эмоций, обозначаемых оксюморонами типа страх счастья, восторг ужаса. Такие многокомпонентные наименования существенно расширяют границы эмоционального мира героев и отражают возможность «совмещения» разных переживаний.

Ключевые слова: эмоции, эмоция страха, художественный текст, Иван Бунин, семантика, языковое моделирование, эмотив.

Цитирование. Киселева Л. А. Параметры языкового моделирования эмоциональных ситуаций в художественном тексте // Вестник Волгоградского государственного университета. Серия 2, Языкознание. - 2018. T. 17, № 3. - C. 108-118. - DOI: https://doi.org/10.15688/jvolsu2.2018.3.11

\section{Введение}

Основы многоаспектного осмысления проблемы «язык и эмоции», характерного для современной лингвистики, были заложены еще Ш. Балли, который писал: «Те из моих мыслей, что порождены потоком жизни, никогда не бывают преимущественно интеллектуальными: это движения мысли, сопровождаемые эмоциями» [Балли, 2003, с. 28]; и далее: «Таким образом, соприкасаясь с реальной жизнью, объективные, на первый взгляд, идеи пропитываются аффективностью» [Балли, 2003, с. 30]. Сосредоточенность лингвистов на исследовании эмоциональной составляющей языка / речи имеет объективные причины: естественный язык является наиболее гибким и динамичным каналом выражения внутренних состояний, что обеспечивает ему семиотическое «превосходство» над другими знаковыми системами передачи эмоциональной информации (подробно см.: [Калимуллина, 2013]). Не случайно в современной лингвистике эмотивная функция наряду с коммуникативной, когнитивной и метаязыковой определяется как базовая функция языка [Слюсарева, 2000, с. 564]. Именно этим объясняются широта и разнообразие эмотивных единиц и средств, относящихся к разным уровням языковой системы. Вполне очевидно, что эмотивный потенциал языка в полном объеме реализуется лишь в рамках текста, где находят лексико-грамматическое выражение коммуникативные стратегии и тактики, связанные с эмоциональным самовыражением адресанта, а также с аналогичным воздействием на адресата. Диапазон эмотивности текстов становится достаточно широким, если иметь в виду их разные тематическую, жанровую и стилистическую прикрепленности (см., например: [Ионова, 2000]). При этом можно полагать, что на полюсах шкалы эмо- тивности располагаются, с одной стороны, устные спонтанные тексты, в которых происходит актуализация непосредственного эмоционального состояния говорящего / слушающего, с другой - художественные прозаические тексты, идейно-эстетической задачей которых является «объемное», многогранное отражение внутренней жизни человека.

Процедуры анализа разных текстов с ненулевой степенью эмотивности неодинаковы с точки зрения использования тех или иных лингвистических методов и приемов. Вместе с тем можно утверждать, что в рамках таких текстов происходит языковое моделирование эмоций как особого типа ситуаций, связанных с человеком, а именно как «внутренних» (интериоризованных). Эмотивный аспект художественного текста представляет собой довольно сложный феномен, однако ведущая роль в выражении авторского знания об эмоциональной сфере принадлежит номинативным эмотивам типа радоваться, бояться, любовь, гнев, грустно и т. п. Высказывания, содержащие эмотивную лексику и фразеологию, отражают эмоциональные ситуации в «свернутом» виде, что и обусловливает их специфическую структуру, изучение которой предполагает «последовательное выделение: 1) двух видов эмоциональных ситуаций - простых (ситуаций неамбивалентных эмоций) и сложных (ситуаций композициональных эмоций, эмоционально-ментальных, эмоционально-волевых ситуаций); 2) основных элементов, то есть дискретных составляющих эмоциональной ситуации - субъекта чувства, самого чувства и его причины; 3 ) набора аспектов (параметров) каждого из элементов ситуации, на основе которых определяется их своеобразие; 4) набора конкретных концептуальных признаков, объединяемых тем или иным параметром» [Калимуллина, 1999, с. 151]. 


\section{РАЗВИТИЕ И ФУНКЦИОНИРОВАНИЕ РУССКОГО ЯЗЫКА}

Следует подчеркнуть, что компоненты эмоциональной ситуации, как правило, в языковой форме акцентируются адресантом текста, о чем свидетельствует прежде всего частота употребления определенных эмотивов и специфика их контекстуальных связей, то есть преимущественные комбинации с лексемами, относящимися к тем или иным семантическим сферам. Именно поэтому в качестве средств текстовой вербализации эмоций выступают не отдельные эмотивы, а их разнообразные сочетания внутри линейно не связанных высказываний, в результате исследования которых моделируется «идеальная» эмоциональная ситуация, соотносимая с переживанием того или иного внутреннего состояния.

Возможность анализа языкового моделирования эмоций в художественном тексте мы хотели бы продемонстрировать на материале лирической прозы И.А. Бунина - рассказов цикла «Темные аллеи». Обращение к творчеству этого автора не случайно: эмоциональная сфера имеет для него первостепенную значимость в связи с тем, что, по мнению писателя, восприятие и понимание мира человеком возможны только через чувство. «Gefuhl ist alles чувство все. Гете. Действительность - что такое действительность? Только то, что я чувствую. Остальное вздор», - писал И.А. Бунин в «Окаянных днях» (М. : Молодая гвардия, 1991. С. 123). Как полагают критики, доминирование авторской рефлексии посредством сосредоточенности на чувственной стихии во многом свидетельствует об импрессионистическом характере поздней прозы писателя: «У Бунина тяготение к импрессионизму проявляется значительно нагляднее, чем у Чехова, - и в этом сказались, в немалой степени, его поиски экспрессивных средств для передачи трудноуловимых душевных состояний» [Гейдеко, 1976, с. 307]. Важно, что Бунин стремится познать и многогранно, объемно представить не человеческую психику вообще, а именно русскую душу, ее сущностные основы, которые во многом определяют своеобразие жизненного и исторического пути русских людей: «Меня занимает душа русского человека в глубоком смысле, изображение черт психики славянина» (цит. по: [Мраморнов, 1995, с. 238]).

\section{Структура эмоционального плана художественного текста}

В рассказах цикла «Темные аллеи» представлены лексико-фразеологические манифестанты более 50 видов эмоциональных явлений. К ним относятся прежде всего базовые (фундаментальные, первичные) эмоции радости, печали, гнева, удовольствия, страха и т. д., которые выделяются психологами на основе нескольких критериев: «1) базовые эмоции имеют отчетливые и специфические нервные субстраты; 2) базовая эмоция проявляет себя при помощи выразительной и специфической конфигурации мышечных движений лица (мимики); 3) базовая эмоция влечет за собой отчетливое и специфическое переживание, которое осознается человеком; 4) базовые эмоции возникли в результате эволюционно-биологических процессов; 5) базовая эмоция оказывает организующее и мотивирующее влияния на человека, служит его адаптации» [Изард, 2003, с. 63-64]. Кроме того, в поздней прозе Бунина находят языковое выражение и так называемые «культурные» (социальные) эмоции уважения, любви, ненависти, зависти и пр., которые выступают результатом межличностного взаимодействия, а потому весьма своеобразно регулируются этикетными и иными нормами, закрепившимися в рамках конкретной культуры.

В поздней новеллистике И.А. Бунина сфера внутренних переживаний персонажей выступает как сложное, разноплановое образование, поскольку внутри него выделяются как минимум две разновидности эмоций: доминантные и второстепенные. Наиболее очевидным основанием их дифференциации выступают количественно-статистические данные (в первую очередь частотность авторского использования номинативных эмотивов с определенной семантикой), с опорой на которые можно отнести к доминирующим эмоциям радость, любовь, счастье, печаль, страх, гнев, а ко второстепенным - обиду, отвращение, волнение, растерянность, зависть и т. д. Вместе с тем следует подчеркнуть, что количественные данные не являются самоценными, они значимы лишь как показатели того, какую роль играют эмотивные единицы, репрезентирующие то или иное внутреннее пере- 
Л.А. Киселева. Параметры языкового моделирования эмоциональных ситуаций в художественном тексте

живание, в выражении индивидуально-авторской картины мира. В связи с этим необходимо иметь в виду следующее: «Еще в дореволюционный период творчества Бунина критики отмечали в его прозе и поэзии мотив “мертвой печали", который в эмигрантские годы значительно усилился, перерос в символический лейтмотив. Скорбь и “тоска бытия” были порождением ясно осознаваемой автором конечности своего существования, которую он не мог объяснить, но не хотел и принять. <..> При этом у Бунина ужас небытия неразрывно связан с не менее острой жаждой жизни и любви к ней, проявляющейся прежде всего в преклонении перед красотой мира, которая вызывает в человеке радость, подъем чувств» [Калимуллина, 1999, с. 145]. Следовательно, сосредоточенность автора на изображении определенного круга эмоциональных переживаний во многом позволяет ему раскрыть важнейшие идейно-эстетические принципы своего творчества: «...прекрасное соотносится с любовью, радостью, счастьем, а трагическое - с тоской, печалью, страхом, мукой» [Калимуллина, 1999, с. 146]. По этой причине большой интерес представляет анализ эмотивов страха, которые в цикле «Темные аллеи» образуют особый лексико-фразеологический пласт, значимый и качественно, и количественно. Бунин отводит страху ведущую роль в раскрытии внутреннего мира персонажей, поскольку, по его мнению, данная эмоция определяет не только содержание разнообразных жизненных ситуаций, но человеческое существование во всех его проявлениях, в том числе в своеобразии внутренней сферы в целом.

В соответствии со сказанным выше среди эмоциональных ситуаций страха, моделируемых в прозе Бунина, нами выделяются две разновидности (простые и сложные ситуации), при этом основополагающим является формально-структурный критерий, согласно которому простые эмоциональные ситуации выражаются одиночными эмотивами страха (бояться, испугаться, страх, страшно и т. д.), а сложные - разнообразными сочетаниями данных эмотивов с обозначениями других внутренних переживаний (боюсь и радуюсь; дивился, ужасался; ужас восторга и т. п.). Рассмотрим их подробнее.

\section{Простые эмоциональные ситуации страха}

Параметр причинной обусловленности эмоции. Страх, как и другие эмоциональные явления, характеризуется свойством предметности, то есть связан с оценкой того или иного лица, события и т. д. чувствующим субъектом, при этом источник страха может находиться как в его внутренней сфере, так и во внешнем мире. В прозе И.А. Бунина в качестве «внутренней» причины страха предстают определенные психические процессы (эмоциональные, интеллектуальные, волевые и т. д.): Я подумала: "А вдруг правда убьют? И неужели я все-таки забуду его в какой-то короткий срок - ведь все в коние кониов забывается?» И поспешно ответила, испугавшись своей мысли: - Не говори так! Я не переживу твоей смерти! (Холодная осень) ${ }^{1}$. Особое место в цикле «Темные аллеи» отводится обрисовке страха как негативного отношения персонажей к собственной деятельности и действиям, препятствующим их осуществлению: И мальчик, от природы живой, ласковый, стал в их присутствии бояться слово сказать, а там и совсем затаился, сделался как бы несуществующиим в доме (Красавица). Употребление субъектного инфинитива свидетельствует о том, что причина страха находится «внутри» самого чувствующего лица, выступая как «осознание нежелательности достижения цели, противоречащего его интересам» [Чернова, 1996, с. 81-82]. В данном случае имеются в виду собственные действия, поступки субъекта, эмоции, для которых характерен признак контролируемости: человек по своей воле может как совершить их, так и оказаться от этого (примечательно, что в рассказах Бунина, как правило, представлен последний вариант). На наш взгляд, указанное сочетание и подобные ему описывают сложные эмоционально-интеллектуально-волевые ситуации.

Приведенные выше фрагменты сближаются по своей семантике с контекстами, содержащими сочетания, в состав которых входит наречно-предикативный эмотив страшно и субъектный инфинитив: Нет, у меня была, кроме старой улищы, и другая цель, 


\section{РАЗВИТИЕ И ФУНКЦИОНИРОВАНИЕ РУССКОГО ЯЗЫКА}

в которой мне было страшно признаться себе, но исполнение которой, я знал, было неминуемо (Поздний час). Некоторые исследователи считают, что в таких высказываниях на первый план выходит оценка, а значение эмоционального состояния нивелируется [Вольф, 1982, с. 337]. Можно согласиться с тем, что подобные сочетания выражают значение эмоциональной оценки, однако в данном случае репрезентируется единство эмоционального, рационального и волевого начал, которое в отдельных случаях намеренно подчеркивается автором: Я все-таки не решился дойти до вашего дома. И он, верно, не изменился, но тем страшнее увидать его (Поздний час) (ср.: не решился, потому что было страшно увидать).

В поздних новеллах Бунина внешними по отношению к субъекту причинами страха чаще всего выступают социальные феномены, прежде всего актуальные межличностные контакты либо их ментальные заместители (мысли, воспоминания, фантазии и т. п.). Ситуации, вызывающие страх, изображаются писателем как имплицитно, так и эксплицитно. Имплицитно целостное событие обозначается именем его главного участника - лица: И девочка, помогая старухе и прислуживая ему, то и дело пугалась от его быстpых, внезапных взглядов на нее... Он и без того был страшен ей (Ночлег). В таких контекстах «имена лиц-каузаторов страха характеризуются диффузной семантикой: они подразумевают одновременное наличие и конкретного референта - лица, своим присутствием вызывающего чувство страха, и обобщенного, генерализованного референта - целого класса событий, связанных с определенным лицом, то есть множества его свойств и проявлений, каузирующих страх. Несомненно, это сближает анализируемые эмотивы страха (бояться, быть страшным) с предикатами эмоционального отношения типа любить, npeзирать кого и под.» [Калимуллина, 1999, c. 174]. В цикле «Темные аллеи» внешняя причина страха выражается эксплицитно («развернуто») - как определенное «положение дел» в мире. При описании таких ситуаций Бунин, как правило, подчеркивает преобладание либо эмоционального, либо интеллектуального начала в их оценке. Так, эмоциональное доминирует в тех случаях, когда страх является непосредственной реакцией персонажей на какие-либо свойства, действия, поступки лица-каузатора: - Я боюсь, что это вы на меня так смотрите? (Таня). Ведущая роль интеллектуального начала выражается использованием предикатов со значением психологической оценки целостных событий: И везде невообразимая тишина - только комары ноют и стрекозы летают. Никогда не думал, что они летают по ночам, оказалось, что зачем-то летают. Прямо страшно (Руся). Употребление предикатов типа страшно, жутко и т. п. в составе парцеллированных конструкций, которые имеют резюмирующий характер, указывает на рациональное отношение к этим ситуациям. Интеллектуальный компонент преобладает и в тех случаях, когда негативной оценке подвергаются ситуации не реального, а «возможного» мира, то есть ментальные аналоги естественных событий: - Позвольте войти, боюсь, кто-нибудь усльиит... (Антигона). В приведенном примере описывается ситуация опасения, то есть своеобразного «предстраха», вызываемого мыслью о таких событиях, которые представляются героям не только возможными, но и высоковероятными, и при этом не поддаются контролю. По мнению некоторых исследователей, глагол бояться выступает здесь в качестве предиката мысли (см.: [Зализняк, 1983, с. 62]). На наш взгляд, в данном случае эмоциональный момент нельзя игнорировать, поскольку он в том или ином виде (например, как волнение, беспокойство, тревога, то есть близкие страху состояния) всегда присутствует в ситуации опасения. Приведенные и подобные им примеры подтверждают тезис о холистическом характере психики, неразрывном единстве всех ее компонентов.

Итак, в поздней новеллистике Бунина параметр причинной обусловленности страха, связанный с описанием соответствующих эмоциональных ситуаций, объединяет такие признаки, как 'предметность эмоции', 'внутренняя / внешняя причинная обусловленность', 'связь с интеллектуальной и волевой сферами', 'направленность / ненаправленность', 'интенциональность / неинтенциональность каузации'. 
Параметр временно́й локализованности эмоции. Исходные эмотивы страха бояться и быть страшным в конкретном контекстуальном окружении могут обозначать, во-первых, не зависящее от временно́го фактора эмоционально-рациональное отношение субъекта к событиям, лицам, предметам и т. д., во-вторых, актуальное внутреннее состояние, относящееся к определенному временно́му отрезку, то есть переживаемое «здесь и сейчас». В первом случае писатель подчеркивает возникновение чувства, приобретающего постоянный характер, либо его прекращение: И мальчик, от природы живой, ласковый, стал в их присутствии бояться слово сказать, а там и вовсе затаился, сделался как бы несуществуюшим в доме (Красавица).

Другие эмотивы страха в поздней прозе И.А. Бунина выражают лишь актуальное временно́е значение, то есть репрезентируют испытываемое тем или иным персонажем эмоциональное состояние, для которого характерны как динамические, так и статические признаки. Переживание страха персонажами рассказов Бунина не связано с признаком длительности, а потому изображается писателем как эмоциональное состояние, а не процесс. Именно поэтому динамический аспект страха представлен лишь его фазисными параметрами. Писатель выделяет две крайние точки на временно́й оси протекания эмоции: ее возникновение и прекращение. Описание момента возникновения страха связано с акцентированием признака результативности: $-A$ Шаляпин как рявкнет: «В Сибири сгною, в кандалы закую - слушай мой приказ!» Тут дядя сразу испужался... (Второй кофейник). Лексико-фразеологические эмотивы испугаться, охватил страх и подобные им репрезентируют возникновение страха как некое внутреннее (психическое) «событие», которое отличается внезапным характером, о чем свидетельствует активное использование в таких конструкциях наречий с темпоральной семантикой: сразу, вдруг и т. д. Напротив, контексты, в которых на первый план выходит признак нерезультативности, описывают не возникновение страха, а его переживание: Не то при встрече с женщиной: он не токмо не боится ее, но, зная, что тут ее самое ужкас u похоть берет, козлом плямет к ней... (Железная шерсть). Важным нам кажется тот факт, что в цикле «Темные аллеи» «конечная точка» переживания страха изображается крайне редко. Вероятно, это объясняется тем, что в отличие от момента возникновения эмоции, который служит сигналом определенного нарушения эмоционального равновесия, как правило, имеющего довольно четкие внешние (прежде всего физиологические) симптомы, прекращение эмоции воспринимается чувствующим лицом как менее заметное и потому слабо различаемое. При этом в поздних новеллах Бунина «конечная точка» страха предстает как переход к спокойному (нейтральному) состоянию: Она облегченно передохнула: - Ах, какая гадость! Недаром слово ужас происходит от ужа... (Руся). Статические признаки страха как актуального эмоционального состояния, переживаемого лицом в определенный временной момент, в цикле «Темные аллеи» описываются довольно кратко, при этом основными средствами их репрезентации являются наречно-предикативные формы страшно и жутко: - Где ты был? Мне страшно, зажги скорей огонь... (Натали).

Таким образом, временно́й параметр страха связан с разграничением целого ряда составляющих его признаков: 'временна́я актуализованность (эпизодичность) / вневременность (стабильность)', 'статичность / динамичность', 'фазисность протекания', 'кратность переживания’.

Параметр интенсивности эмоции. В поздней прозе Бунина эмоциональная ситуация страха характеризуется признаком градуативности, который реализуется в дифференциации трех зон интенсивности данной эмоции (средней, высокой и максимальной), при этом основной является средняя степень интенсивности страха, обозначаемая исходными эмотивами бояться, испугаться, страшно и т. п. Переживание большой силы страха описывается в рассказах цикла с помощью разнообразных сочетаний данных единиц с определенными лексемами (прежде всего наречиями), эксплицитно выражающими семантику интенсивности: На столе среди комнать блестел большой револьвер с барабаном и длинным дулом, на кровати рядом с его 
кроватью бельм бугром была навалена его верхняя одежда. Все это было очень жутко (Ночлег).

Необходимо отметить один важный момент: если зона средней интенсивности страха описывается в поздних новеллах Бунина как довольно четко отграниченная от зон высокой и максимальной силы эмоции, то две последние, как правило, представлены диффузно и потому с трудом могут быть дифференцированы. Например, сочетания типа насмерть испужалась, напугаться до смерти и т. п., на первый взгляд, описывают максимальную степень интенсивности страха, однако, по мнению автора, это еще не предельная сила чувства: - Напугалась грозы до смерти, а тут сльши, ктой-то подъехал, еще пуще испуzалась... (Степа). Следовательно, нельзя однозначно утверждать, что приведенные и аналогичные им выражения репрезентируют лишь одну зону интенсивности страха. На наш взгляд, максимальная сила страха описывается в цикле «Темные аллеи» как аффект, то есть особый психический феномен, не поддающийся рациональному контролю: - Вскочил вдруг от мольберта, бросил палитру с кистями и сбил мине с ног на ковер. Я испужалась до того, что и крикнуть не смогла (Второй кофейник). Максимальная (аффективная) степень страха выражается также лексемой ужсас, которая обозначает «не только крайнюю степень эмоционального напряжения, но и своего рода интеллектуальный “стресс", вызванный невозможностью разрешения какой-либо проблемы, вопроса и т. д. Подтверждением этому служат сочетания данных эмотивов с предикатами мысли, памяти, интеллектуальных эмоций, вводящие внутреннюю речь рассуждающего типа» [Калимуллина, 1999, с. 180], например: На веретьях сидели, работая, бабы и девки, закутанные в пеньковые шали, в рваных куртках, в разбитых валенках, с посиневшими лицами и руками, - он с ужсасом думал: а под подолами у них совсем голье ноги! (Таня).

Таким образом, параметр интенсивности страха объединяет ряд частных признаков: 'градуативность', 'размытость шкалы интенсивности', 'аффективная степень интенсивности (эмоциональный / «интеллектуальный» аффект)', 'интенсификация'.
Параметр внешнего проявления эмоции. В поздних новеллах Бунина внешняя симптоматика страха описывается двумя способами: 1) посредством так называемых «симптомных» выражений, обозначающих разного рода соматические признаки эмоции, а именно сочетаний типа дрогнуть от стра$x a$, похолодеть от страха и их функциональных аналогов - усеченных форм, не включающих эмотивы (содрогнуться, похолодеть и под.); 2) посредством комбинации эмотивов страха с наименованиями тех видов социальной жизнедеятельности человека, которые также можно считать довольно эффективными каналами внешнего проявления данной эмоции (речь, поступки и т. д.).

В цикле «Темные аллеи» языковые единицы первого типа представлены намного шире, то есть внешняя экспрессия страха предстает прежде всего как «телесный» язык, связанный с биологическим, инстинктивным началом в человеке, а потому в центре внимания писателя оказываются мимические и физиологические проявления данной эмоции. Наиболее открытый канал мимического выражения страха - взгляд: ...меня просто поражает своей красотой ужаснейший испуг, вдруг мелькнувший в ее блестящих слезами глазах... (Речной трактир). Примечательно, что в поздних рассказах Бунина зрительная экспрессия страха характеризуется свойством условности, так как именно она допускает намеренную имитацию: $\boldsymbol{Я}$ шутя сделал страшные глаза: - Ой, какой ужас (Чистый понедельник).

Физиологические реакции, связанные с переживанием страха, изображаются писателем либо «изнутри» (как фиксируемые лишь самим чувствующим субъектом), либо «извне» (как доступные наблюдению). Основное отличие лексем со значением физиологических симптомов страха от средств описания других невербальных его признаков состоит в том, что первые чаще всего соотносятся с высокой интенсивностью эмоции. В поздней прозе Бунина биологические проявления страха изображаются в виде двух типов реакций: 1) кратковременного экстраординарного функционирования определенных систем организма; 2) кратковременной остановки в функционировании данных систем [Иорданская, 1972, 
с. 9]. Первый из них представлен в цикле «Темные аллеи» такими разновидностями, как дрожь и температурные изменения. Они описываются посредством концептуальной метафоры «страх - это холод», носящей традиционный характер и свойственной системе языка [Добровольский, 1996, с. 84]: Кондуктору, который проводил ее ко мне и перенес ее вещи, я ледяной рукой сунул десятирублевую бумажку... (Кавказ). В поздних новеллах Бунина сильный страх, находящий свое внешнее проявление в виде температурных реакций, репрезентируется также с помощью когнитивной метафоры «страх - это жар»: - Я к тебе нынче ночью приду.. - Ее точно обожглл, - первое время старуха приводила ее в ужсас: - Ой, что вbl, что вы!! Я с ума от страха сойду! (Таня). Образная семантика данных метафорических моделей вполне поддается объяснению, если учитывать то, что эффекты жара и стужи в чем-то сходны [Арутюнова, 1997, с. 67]. Это дает основание утверждать, что указанные метафорические модели описывают сходные физиологические симптомы страха. При этом если приведенные выше языковые единицы не всегда обозначают протекающие в организме физиологические процессы, связанные с переживанием страха, то параэмотивы типа дрожать от страха, дрогнуть от страха и аналогичные им описывают реальные соматические проявления данной эмоции, которые к тому же доступны внешнему наблюдению: Он приостановился, вглядываясь, и вдруг дрогнул от страха и неожиданности: с балкона раздался негромкий и ровный, без выражения голос... (Зойка и Валерия). В поздней новеллистике Бунина такие выражения иногда используются в особом контекстуальном окружении, приобретая образный смысл, в связи с чем их значение, связанное с физиологическими признаками страха, «затемняется», отходит на второй план: ...я ещуе издали увидал, что по западной стене дома все окна в зале закрыты ставнями, и соорогнулся от страшной мысли: за ними лежал он и была она! (Натали).

Языковые единицы, обозначающие второй тип физиологических симптомов страха (кратковременную остановку в функционировании определенных систем организма), как правило, в образной форме описывают такое органическое изменение, как прекращение двигательной активности лица, испытывающего это состояние: Войдя к себе, я, не зажигая свечи, сел на диван и застыл, оцепенел в том страшном и дивном, что так внезапно и неожиданно свершилось в моей жизни (Натали). В поздней прозе И.А. Бунина встречаются также контексты, в которых внешнее проявление страха представлено как нарушение жизнедеятельности многих или (в крайних случаях) всех систем организма, что выражается посредством квантора всеобщности. При этом, как и в приведенных выше примерах, актуализируется когнитивная метафора «страх - это холод»: И был темный, отвратительный вечер, когда я ехал на вокзал, все внутри у меня замирало от тревоги и холода (Кавказ).

В цикле «Темные аллеи» большое место отводится также обрисовке комплексной экспрессии страха. Нами выделено два типа таких контекстов: 1) описание ряда соматических признаков страха, связанных с активным функционированием разнообразных физиологических систем и последующим прекращением их деятельности: ...вдруг что-то мелькнуло и с бешеной быстротой, темнымм клубком понеслось на меня - я, вне себя, шарахнулся в сторону, вся голова у меня сразу обледенела и стянулась, сердце рванулось и замерло... Что это было? Пронеслось и скрылось. Но сердие в груди так и осталось стоять (Поздний час); 2) описание внешней экспрессии страха как одновременного физиологического и речевого проявления данной эмоции: [Руся] вдруг дико взвизгнула и подхватила сарафан до самых колен, топая ногами: - Уж! Уж! (Руся). Как можно заметить, писатель подчеркивает тесную связь вербального и невербального каналов выражения страха, свидетельством чего является тот факт, что обозначения соматических признаков этой эмоции выступают функциональными аналогами глаголов речи.

Таким образом, параметр внешней экспрессии страха предполагает выделение целого ряда частных признаков, образующих определенную систему: 'вербальное / невербальное (мимическое и физиологическое) вы- 


\section{РАЗВИТИЕ И ФУНКЦИОНИРОВАНИЕ РУССКОГО ЯЗЫКА}

ражение', 'условность экспрессии', 'комплексность внешних симптомов’ и др.

\section{Сложные эмоциональные ситуации страха}

В поздних новеллах И.А. Бунина ситуации двойственных (смешанных) эмоций описываются посредством ряда оксюморонов, в числе которых выделяются ключевые в содержательном отношении сочетания, во многом определяющие авторские стратегии обрисовки сложных психических феноменов. Онтологически страху не противопоставляется какое-либо позитивное внутреннее состояние, именно поэтому обозначения других эмоций, которые сочетаются с эмотивами страха, можно рассматривать как контекстуальные антонимы последних. Мы выделили несколько направлений описания композициональных эмоций в поздней прозе И.А. Бунина.

Эмотивы страха образуют сочетания с наименованиями позитивных эмоций, которые либо обобщенно описывают внутреннее состояние: - До чего хорошо, господи! - Чем хорошо, Машенька? - Тем и хорошо-с, что сам не знаешь чем. Жутко (Баллада), либо конкретизируют его, указывая на определенное переживание: - Прошло мое времечко, сказала она. - Вскочу, бывало, к вам - и боюсь до смерти и радуюсь: ну, слава богу, старуха заснула (Таня). Для поздней прозы Бунина характерна тенденция к активному использованию оксюморонов, в основе которых лежат авторские представления о возможности одновременного переживания таких различных по субъективному качеству эмоций, как радость и страх. Эти представления находят свое формальное выражение, во-первых, в комбинации исходных номинантов радости и страха: Вся замирая от радостного страха, высоко подняла она платье над белой коленкоровой юбкой, вошла в шарабан и села рядом с ним... (Таня); во-вторых, в сочетании эмотивов со значением аффективной интенсивности этих эмоций, то есть ассоциативной модели «ужас - восторг»: И, подойдя, с ужнасом восторга взглянул на иноческую стройность ее черного платья, на чистую, молодую красоту лица, реснии и глаз, при виде меня опустившихся... (Натали). Как можно заметить, индивидуально-авторские оксюмороны, в состав которых входят эмотивы страха и радости, отличаются алогизмом, так как описывают одновременное переживание исключающих друг друга эмоций.

Для поздней новеллистики И.А. Бунина характерны сочетания эмотивов страха с обозначениями таких внутренних состояний, которые отличаются оценочной амбивалентностью, то есть в зависимости от ситуации предстают в виде либо позитивного, либо негативного переживания. Данные комбинации представляют собой однородные ряды эмотивов с сочинительной связью, благодаря которым уточняется субъективное содержание таких амбивалентных внутренних состояний, как удивление, смущение и др.: Узнал, испугался, сконфузился, - стоит, растерянно смотрит на меня: «Маша, ты?? (Месть); ...и все дивился, ужсасался: за что так наказал меня бог, за что дал сразу две любви, такие разные и такие страстные... (Натали).

Если же иметь в виду указанные выше параметры языкового моделирования эмоциональных ситуаций, то при описании смешанных внутренних переживаний И.А. Бунин отдает предпочтение следующим из них:

1) параметр интенсивности эмоции, который выражается либо одиночными эмотивами, обозначающими ее максимальную силу (ужас, ужсасался и т. д.), либо сочетанием исходных эмотивов с другими лексемами, имеющими значение высокой интенсивности, например: $u$ боюсь до смерти, и радуюсь;

2) параметр внешнего проявления эмоций, прежде всего физиологического и мимического: так, большая роль отводится описанию взгляда как наиболее открытого, следовательно семиотизированного телесного сигнала эмоциональных переживаний, например: с ужасом восторга взглянул и т. п.

\section{Заключение}

Как свидетельствуют результаты проведенного анализа, выделенные нами параметры языкового моделирования эмоциональных ситуаций в художественном тексте во многом носят универсальный характер, поскольку отражают важнейшие онтологические характе- 
ристики внутренних состояний. Прежде всего, это те параметры, которые связаны с основными компонентами эмоциональной ситуации (субъектом, объектом (причиной) и самим внутренним переживанием), а именно параметры причинности, темпоральности, интенсивности и внешней экспрессии эмоций. Вместе с тем с опорой на определенные художественные тексты (в данном случае цикл рассказов И.А. Бунина «Темные аллеи») можно говорить об индивидуально-авторской специфике качественной и количественной репрезентаций данных параметров, обусловленных, с одной стороны, системными отношениями эмотивов, которые проецируются на смысловое пространство текста, с другой ассоциативными связями этих единиц в пределах конкретных произведений.

На примере эмотивов страха показано, что отдельные признаки, составляющие названные параметры, обнаруживают определенную взаимосвязь: темпоральные характеристики страха ('временна́я ограниченность', 'статичность / динамичность' и др.) соотносятся с некоторыми признаками, объединяемыми каузативным параметром ('ситуативность' и т. д.). При описании отдельных параметров страха И.А. Бунин активно использует образные ресурсы языка: в частности, внешние признаки данной эмоции репрезентируются с помощью концептуальных метафор «страх - это холод» и «страх - это жар», которые обозначают близкие по качеству физиологические симптомы.

Особое внимание в цикле «Темные аллеи» уделяется раскрытию не только сложных внутренних состояний героев, эмоционально-волевых и эмоционально-ментальных, но и комплексов (диады и триады) эмоций, обозначаемых с помощью оксюморонов типа восторженный ужас, радостный страх счастья. Количество подобных единиц довольно велико, в связи с чем можно говорить об особенностях авторской обрисовки сферы emotio.

\section{ПРИМЕЧАНИЕ}

1 Здесь и далее примеры приводятся по источнику: Бунин И.А. Темные аллеи // Собрание сочинений : в 4 т. М. : Правда, 1988. Т. 4. С. 5-222.

\section{СПИСОК ЛИТЕРАТУРЫ}

Аругюнова Н. Д., 1997. О стыде и стуже // Вопросы языкознания. № 2. С. 59-70.

Балли Ш., 2003. Язык и жизнь. Пер. с фр. М. : Едиториал УРСС. 232 с.

Вольф Е. М., 1982. Состояние и признаки. Оценки состояния // Семантические типы предикатов. М. : Наука. С. 320-339.

Гейдеко В. А., 1976. Чехов и Ив. Бунин. М. : Советский писатель. 376 с.

Добровольский Д. О., 1996. Образная составляющая в семантике идиом // Вопросы языкознания. № 1. С. 71-93.

Зализняк Анна А., 1983. Семантика глагола бояться в русском языке // Известия АН СССР. Серия литературы и языка. Т. 42, № 1. С. 59-66.

Изард К., 2003. Психология эмоций. Санкт-Петербург : Питер. 464 с.

Ионова С. В., 2000. Когнитивный подход к исследованию текстовой эмотивности // Вестник Волгоградского государственного университета. Серия 2: Филология. Журналистика. Вып. 5. С. 116-121.

Иорданская Л. Н., 1972. Лексикографическое описание русских выражений, обозначающих физические симптомы чувств // Машинный перевод и прикладная лингвистика. Вып. 16. М. : Изд-во Московского гос. пед. ин-та ин. яз. С. 3-30.

Калимуллина Л. А., 1999. Эмотивная лексика и фразеология русского литературного языка (синхронический и диахронический аспекты) : дис. ... канд. филол. наук. Уфа. 348 с.

Калимуллина Л. А., 2013. Семиотическая сущность невербального эмоционального кода и специфика его номинации (на материале славянских языков) // Przegląd Wschodnioeuropejski. IV. C. 533-545.

Мраморнов О., 1995. Иван Бунин перед загадкой русской души // Новый мир. № 9. С. 236-240.

Слюсарева Н. А., 2000. Функции языка // Языкознание: Большой энциклопедический словарь. 2-е изд. М. : Большая Российская энциклопедия. С. 564-565.

Чернова С. В., 1996. Модальные глаголы в современном русском языке. Семантическая модель «замысел - осуществление замысла». Киров : Изд-во Вятского гос. пед. ун-та. 168 с.

\section{REFERENCES}

Arutyunova N.D., 1997. About shame and icy cold. Voprosy yazykoznaniya [Topics in the Study of Language], no. 2, pp. 59-70.

Balli Sh., 2003. Language and life. Moscow, Editorial URSS Publ. 232 p. 


\section{РАЗВИТИЕ И ФУНКЦИОНИРОВАНИЕ РУССКОГО ЯЗЫКА}

VolfE.M., 1982. Condition and features. Evaluation of condition. Semanticheskie tipy predikatov. Moscow, Nauka Publ., pp. 320-339.

Geydeko V.A., 1976. Chekhov and Bunin. Moscow, Sovetskiy pisatel Publ. $376 \mathrm{p}$.

Dobrovolskiy D.O., 1996. Figurative component in the semantics of idioms. Voprosy yazykoznaniya [Topics in the Study of Language], no. 1, pp. 71-93.

Zaliznyak A.A., 1983. Semantics of verb fear in the Russian language. Izvestiya AN SSSR. Seriya literatury i yazyka, vol. 42, no. 1, pp. 59-66.

Izard K., 2003. Psychology of emotions. Saint Petersburg, Piter Publ. 464 p.

Ionova S.V., 2000. Cognitive approach to research of textual emotiveness. Vestnik Volgogradskogo gosudarstvennogo universiteta. Seriya 2: Filologiya. Zhurnalistika [Science Journal of Volgograd State University. Philology. Journalism], iss. 5, pp. 116-121.

Iordanskaya L.N., 1972. Lexicographic description of phrases with the meaning of physical symptoms of emotions in the Russian language. Mashinnyy perevod $i$ prikladnaya lingvistika [Machine Translation and Applied Linguistics]. iss. 16, pp. 3-30.

Kalimullina L.A., 1999. Emotive lexicon and phraseology of the Russian literary language (synchronic and diachronic aspects). Dr. philol. sci. diss. Ufa. 348 p.

Kalimullina L.A., 2013. Semiotic essence of nonverbal emotional code and specifity of its nomination (on the material of Slavonic languages). Przeglad Wschodnioeuropejski, no. IV, pp. 533-545.

Mramornov O., 1995. Ivan Bunin against the mystery of Russian soul. Novyy mir, no. 9, pp. 236-240.

Slyusareva N.A., 2000. Language functions. Linguistics: Large Encyclopedic Dictionary. Moscow, Bolshaya Rossiyskaya entsiklopediya Publ., pp. 564-565.

Chernova S.V., 1996. Modal verbs in the Russian language. Semantic model 'Plan Realization of Plan'. Kirov, Izd-vo Vyatskogo gos. ped. un-ta. $168 \mathrm{p}$.

\section{Information about the Author}

Larisa A. Kiseleva, Doctor of Sciences (Philology), Associate Professor, Professor of Department of Theory of Language and the Methods of Its Teaching, Bashkir State University, Zaki Validi St., 32, 450076 Ufa, Russia, larisakiseleva2015@yandex.ru, https://orcid.org/0000-0002-4875-6435

\section{Информация об авторе}

Лариса Айратовна Киселева, доктор филологических наук, доцент, профессор кафедры теории языка и методики его преподавания, Башкирский государственный университет, ул. Заки Валиди, 32, 450076 г. Уфа, Россия, larisakiseleva2015@yandex.ru, https://orcid.org/0000-0002-4875-6435 